Uniwersytet Mikołaja Kopernika w Toruniu

Katedra

Edward Dolny

\title{
AKTYWNE PROGRAMY RYNKU PRACY W POLSCE W LATACH 2005-2009
}

Z a r y s tre ś c i. W opracowaniu dokonano analizy kształtowania się rozmiarów i struktury wydatków z Funduszu Pracy na aktywne programy rynku pracy, liczby i struktury bezrobotnych nimi objętych oraz ich efektywności zatrudnieniowej i kosztowej w Polsce w latach 2005-2009.

Słow a kluczowe: rynek pracy, polityka rynku pracy, aktywne programy rynku pracy.

\section{WPROWADZENIE}

Bezrobocie jest jednym z najpoważniejszych problemów społecznych i gospodarczych w dzisiejszym świecie, przynoszących olbrzymie i niewspółmierne do ewentualnych korzyści straty. Walka z nim wymaga zaangażowania znacznych sił ludzkich i środków materialnych, pochodzących zfunduszy publicznych. Tym ważniejsze jest więc aby środki te były wykorzystywane w sposób racjonalny. Ocena efektywności stosowanych aktywnych instrumentów polityki rynku pracy nie jest sprawą prostą, bowiem ich rezultaty zaciemniane są występowaniem efektów pozornych, a ponadto stosowane mierniki efektywności nie zawsze dostosowane są do celów, których realizację oceniane narzędzia powinny zapewniać. Problemy te są dość dobrze rozpoznane i opisane w literaturze przedmiotu, ale nie znalazły, jak dotąd, adekwatnego do potrzeb wyjaśnienia. Zachowują więc ciągle swoją aktualność i tym samym zasługują na dalsze badanie. 
Celem niniejszego opracowania jest przedstawienie programów składających się na aktywną politykę rynku pracy stosowanych w Polsce oraz źródeł ich finansowania w latach 2005-2009. Omówiono ich rozmiary, dynamikę i strukturę oraz efektywność. Podjęto próbę krytycznej analizy i oceny stosowanych mierników efektywności, wskazując na niepełną ich adekwatność w przypadku pomocy w poszukiwaniu pracy i proponując ich uzupełnienie.

Realizując cel pracy przeprowadzono analizę deskryptywną w oparciu o studiowanie literatury przedmiotu oraz badanie dokumentów, wykorzystując statystyczne narzędzia analizy struktury i dynamiki zjawisk.

\section{SYTUACJA NA RYNKU PRACY}

W 2004 r. wprowadzono ustawę o promocji zatrudnienia i instytucjach rynku pracy (Dz. U. 2004, nr 99, poz. 1001), która miała na celu dostosowanie polskiej polityki rynku pracy do Europejskiej Strategii zatrudnienia. Dokonała ona również podziału działań aktywizujących bezrobotnych na usługi i instrumenty rynku pracy. Usługi rynku pracy obejmowały pomoc w poszukiwaniu pracy, na którą składały się: pośrednictwo pracy, poradnictwo zawodowe wraz z informacją zawodową i pomoc $\mathrm{w}$ aktywnym poszukiwaniu pracy oraz organizacja szkoleń. Zostały one obudowane szeregiem tzw. instrumentów wspierających. W celu aktywizacji zawodowej bezrobotnych wprowadzono natomiast następujące instrumenty rynku pracy: prace interwencyjne, roboty publiczne, przygotowanie zawodowe w miejscu pracy, staże i środki na tworzenie miejsc pracy.

Od 2004 r. dokonano kilkudziesięciu modyfikacji w Ustawie o promocji zatrudnienia i instytucjach rynku pracy z 2004 r. W 2005 r. wprowadzono nowy instrument rynku pracy - prace społecznie użyteczne (Dz. U. 2005, nr 164, poz. 1366), które miały realizować cel raczej socjalny niż aktywizacyjny. Najszerszy zakres miały natomiast zmiany wprowadzone ustawą z grudnia $2008 \mathrm{r}$. (Dz. U. 2009, nr 6, poz. 33), które w przeważającej części zaczęły obowiązywać od 1 lutego 2009 r. Zmiany te zmierzały w kierunku umocnienia PSZ w Polsce i usprawnienia ich pracy, rozszerzyły repertuar możliwych do stosowania usług i instrumentów rynku pracy, umożliwiły efektywniejsze ich wykorzystywanie, bardziej komplementarne i precyzyjne stosowanie, odpowiadające zmieniającym się potrzebom. Zlikwidowano wówczas przygotowanie zawodowe $\mathrm{w}$ miejscu pracy, a w ich miejsce wprowadzono przygotowanie zawodowe dorosłych. Rozszerzono też zakres podmiotowy staży. Dokonane zmiany przepisów prawnych ograniczyły również zbędną biurokrację.

Ożywienie gospodarcze po recesji z początków XXI w. oraz akcesja do Unii Europejskiej, w wyniku której nastąpiło otwarcie rynków pracy dla 
Polaków w wielu krajach Wspólnoty, spowodowały spadek rozmiarów bezrobocia. W 2004 r. sięgało ono liczby 3 mln osób. Do 2008 r. liczba bezrobotnych zmalała do poziomu 1473,8 tys. osób, a stopa bezrobocia obniżyła się o prawie 10 punktów procentowych, do poziomu 9,5\%. Niestety, pod wpływem kryzysu gospodarczego, który pojawił się w USA w 2007 r., a do Europy dotarł w 2008 r., liczba bezrobotnych zaczęła ponownie rosnąć. W końcu 2009 r. liczba bezrobotnych wzrosła do 1892,7 tys. osób, przy stopie bezrobocia $11,9 \%$, a rok później rozmiary bezrobocia przekroczyły $2 \mathrm{mln}$ osób, a stopa bezrobocia $13 \%$.

Tabela 1. Zarejestrowani bezrobotni i poszukujący pracy w Polsce w latach 2005-2009

\begin{tabular}{|c|c|c|c|}
\hline \multirow{2}{*}{ Lata } & Zarejestrowani bezrobotni & Stopa bezrobocia & Poszukujący pracy \\
\cline { 2 - 4 } & \multicolumn{3}{|c|}{ stan w końcu okresu } \\
\hline 2005 & 2773000 & 17,6 & 62107 \\
\hline 2006 & 2309410 & 14,8 & 56768 \\
\hline 2007 & 1746573 & 11,2 & 49360 \\
\hline 2008 & 1473752 & 9,5 & 44409 \\
\hline 2009 & 1892680 & 11,9 & 46176 \\
\hline
\end{tabular}

Źródło: MPiPS, Statystyki rynku pracy,

http://www.psz.praca.gov.pl/main.php? do=ShowPage\&nPID=867997\&pT=details\&sP=CONTE NT, objectID, 867970.

W latach 2005-2009 występowała znaczna płynność rynku pracy. Napływ bezrobotnych malał do 2008 r., kiedy osiągnął poziom poniżej 2,5 mln osób, natomiast w 2009 r. wzrósł o ponad 600 tys. osób. Największy odpływ bezrobotnych wystąpił w 2006 r., kiedy wyniósł 3156 tys. osób. W kolejnych latach malał, aby w 2009 r. osiągnąć poziom 2664,8 tys. osób. Największy udział w odpływie bezrobotnych miały podjęcia pracy; jednak ich udział systematycznie malał z 45,2\% w 2005 r. do 38,0\% w 2009 r. Jednocześnie w populacji podejmujących pracę rósł udział pracy subsydiowanej; zwiększył się w badanym okresie z 13,7\% do $20,0 \%$. Względnie stały był natomiast udział wyrejestrowań z populacji bezrobotnych z powodu niepotwierdzenia gotowości do pracy; kształtował się na poziomie 31-33\%. W latach 2005-2008 odpływ bezrobotnych przewyższał ich napływ (największa różnica wystąpiła w 2007 r. - ponad 560 tys. osób), co skutkowało obniżeniem poziomu bezrobocia. W 2009 r. sytuacja była odwrotna napływ był większy od odpływu (o prawie 420 tys. osób), co wywołało wzrost poziomu bezrobocia. 
Tabela 2. Napływy i odpływy bezrobotnych w Polsce w latach 2005-2009

\begin{tabular}{|c|c|c|c|c|c|}
\hline \multirow{3}{*}{ Lata } & \multirow{2}{*}{$\begin{array}{c}\text { Bezrobotni } \\
\text { zarejestrowani } \\
\text { „napływ” }\end{array}$} & \multirow{2}{*}{$\begin{array}{c}\text { Bezrobotni } \\
\text { wyrejestrowani } \\
\text { „odpływ" }\end{array}$} & \multicolumn{3}{|c|}{ w tym z przyczyn: } \\
\hline & & & podjęcia pracy & $\begin{array}{c}\text { w tym: } \\
\text { subsydiowanej }\end{array}$ & $\begin{array}{l}\text { niepotwierdzenia } \\
\text { gotowości do pracy }\end{array}$ \\
\hline & \multicolumn{5}{|c|}{ w okresie sprawozdawczym } \\
\hline 2005 & 2793181 & 3019782 & 1365790 & 186693 & 993124 \\
\hline 2006 & 2692351 & 3155941 & 1412799 & 163019 & 972176 \\
\hline 2007 & 2491242 & 3054079 & 1266439 & 185766 & 949210 \\
\hline 2008 & 2476583 & 2749404 & 1052077 & 186659 & 874934 \\
\hline 2009 & 3083757 & 2664829 & 1012375 & 202329 & 837751 \\
\hline
\end{tabular}

Źródło: MPiPS, Statystyki rynku pracy, http://www.psz.praca.gov.pl/main.php?do=ShowPage\&nPID=867997\&pT=details\&sP=CONTE NT, objectID, 867970.

Wydatki z Funduszu Pracy przeznaczone na łagodzenie skutków bezrobocia i przeciwdziałanie temu zjawisku utrzymywały się w latach 2005-2008 na podobnym poziomie i wahały się w przedziale 5,4-5,8 mld zk, natomiast w $2009 \mathrm{r}$. wzrosły ponad dwukrotnie do poziomu 11,2 mld zł. Zmieniła się ich struktura. Zmalał udział wydatków na zasiłki i świadczenia z 54,0\% w 2005 r. do 33,2\% w 2008 r. (w 2009 r. wzrósł do 40,1\%), natomiast wzrósł udział wydatków na programy przeciwdziałania bezrobociu z 37,0\% w 2005 r. do 55,2\% w 2009 r. Już sama zmiana struktury wydatkowania środków z Funduszu Pracy spowodowała przeznaczenie większych sum na realizację aktywnych programów rynku pracy.

Tabela 3. Wydatki z Funduszu Pracy w Polsce w latach 2005-2009 w mln zł

\begin{tabular}{|l|c|c|c|c|c|}
\hline \multirow{2}{*}{ Lata } & \multirow{2}{*}{$\begin{array}{c}\text { Wydatki } \\
\text { ogółem }\end{array}$} & \multirow{2}{*}{ Zasitki } & \multicolumn{2}{|c|}{ Programy przeciwdziałania bezrobociu } & \multirow{2}{*}{ Inne } \\
\cline { 4 - 5 } & & & ogółem & aktywne programy rynku pracy & \\
\hline 2005 & 5551 & 2998 & 2052 & 1870 & 456 \\
\hline 2006 & 5500 & 2805 & 2219 & 2029 & 467 \\
\hline 2007 & 5367 & 2268 & 2710 & 2493 & 390 \\
\hline 2008 & 5753 & 1911 & 3362 & 3111 & 480 \\
\hline 2009 & 11245 & 4504 & 6205 & 4016 & 536 \\
\hline
\end{tabular}

Źródło: Polska 2010. Raport o rynku pracy i zabezpieczeniu spolecznym, MPiPS, Warszawa 2010.

W analizowanym okresie, a szczególnie w latach 2008-2009, po wprowadzeniu w 2007 r. szczegółowych warunków prowadzenia przez publiczne służby zatrudnienia usług rynku pracy oraz standardów usług rynku pracy, nastąpiło 
znaczne wzmocnienie kadrowe urzędów pracy. Liczba zatrudnionych ogółem wzrosła o $18,2 \%$, natomiast zatrudnienie na tzw. stanowiskach kluczowych, a więc zaangażowanych w bezpośrednią obsługę bezrobotnych wzrosło o prawie $143 \%$. Udział pracowników na stanowiskach kluczowych wzrósł dwukrotnie osiągając poziom 34,5\% w 2009 r., w tym pośredników pracy do 15,4\% ogółu zatrudnionych $\mathrm{w}$ urzędach pracy.

Wzmocnienie kadrowe publicznych służb zatrudnienia oraz zasilenie systemu aktywizacji zawodowej bezrobotnych dodatkowymi środkami finansowymi zaowocowało rozszerzeniem zakresu stosowania aktywnych instrumentów polityki rynku pracy i zapewne przyczyniło się do zwiększenia ich skuteczności zatrudnieniowej. Zwiększyła się liczba bezrobotnych objętych różnymi usługami i programami aktywnymi rynku pracy, ale wzrósł też koszt uczestnictwa w programie oraz koszt ponownego zatrudnienia.

\section{POMOC W POSZUKIWANIU PRACY}

Pomoc w poszukiwaniu pracy, obejmująca pośrednictwo pracy, poradnictwo zawodowe i pomoc $\mathrm{w}$ aktywnym poszukiwaniu pracy jest działaniem tanim, a zarazem skutecznym. Najlepsze rezultaty przynosi wówczas, gdy kierowana jest do osób o krótkim okresie trwania bezrobocia. W przypadku długotrwale bezrobotnych skuteczność tego działania jest niższa, ale rośnie po skojarzeniu pomocy w poszukiwaniu pracy z innymi formami oddziaływania. Pomoc w poszukiwaniu pracy wpływa na zmniejszenie rozmiarów i natężenia bezrobocia poprzez skrócenie czasu poszukiwania pracy, poprawienie jakości dopasowania pracownika do miejsca pracy i podniesienie trwałości miejsca pracy.

Wzrost liczby zatrudnionych pośredników pracy przy malejących do $2008 \mathrm{r}$. rozmiarach bezrobocia spowodował zmniejszenie liczby bezrobotnych przypadających na 1 pośrednika pracy do 436 osób według stanu w końcu 2008 r. i 538 osób w końcu 2009 r. Wzrost wskaźnika w 2009 r. wynikał ze wzrostu liczby zarejestrowanych bezrobotnych. Nie są to wskaźniki najlepsze, ponieważ nie obejmują całości zadań pośredników pracy. Należałoby raczej wykorzystywać mierniki strumieniowe, informujące o napływach bezrobotnych na rynek pracy i odpływach z niego oraz o pojawiających się ofertach pracy. Tak obliczony wskaźnik pokazał, że w 2009 r. na jednego pośrednika pracy przypadało około 1900 zdarzeń napływu lub odpływu bezrobotnego oraz przyjęcia ofert pracy, przy założeniu, że nowo zarejestrowany bezrobotny kontaktuje się z pośrednikiem tylko jeden raz. Tak więc czas przeznaczony na obróbkę jednego zdarzenia, określający jakość świadczonej usługi, wynosił około 50 minut, z czego znaczną część pochłaniały czynności biurokratyczne, a w praktyce był jeszcze krótszy. 
Niezmiernie trudno jest dokonać oceny efektywności zatrudnieniowej pośrednictwa pracy. Problemy te wynikają z braku odpowiednich informacji statystycznych niezbędnych do oceny tej usługi rynku pracy. Mierniki oceny powinny być dostosowane do celu, którego realizacji dany instrument służy. Ponadto pośrednictwo pracy, jak i inne usługi w zakresie pomocy w poszukiwaniu pracy nie są najczęściej działaniem samoistnym, a stanowią często początkowe ogniwa w łańcuchu usług świadczonych bezrobotnym. Podejmowane są więc badania mające wypełnić istniejące luki w wiedzy dotyczącej tej problematyki. Wyniki tych badań i formułowane na ich podstawie wnioski zostały szeroko opisane w literaturze (Kryńska (red), 2009; Sztanderska, 2008; Wójcicka, Sztandar-Sztanderska, Zieliński, 2008; Kukulak-Dolata, 2007; Szewczyk, 2004; Kryńska, Kwiatkowski, Zarychta, 1998; Zawadzki, 2006). Trudno także obliczyć efektywność kosztową usług świadczonych w ramach pośrednictwa pracy. Wynika to z braku miernika informującego obiektywnie o rozmiarach efektów wyizolowanego działania pośrednictwa pracy z jednej strony oraz jego kosztów z drugiej (Wiśniewski, Zawadzki, 2010).

W latach 2005-2008 liczba bezrobotnych według stanu w końcu okresu przypadających na 1 doradcę zatrudnionego w pup zmniejszyła się z 4614 osób do 1020 osób. W 2009 r. nastąpił wzrost obciążenia, spowodowany wzrostem bezrobocia, do 1298 osób. Bardziej adekwatnym miernikiem wskazującym poziom obciążenia zadaniami jest stosunek napływu bezrobotnych (i napływu poszukujących pracy) do liczby doradców. W latach 2005-2008 wskaźnik obciążenia doradcy zawodowego zatrudnionego w pup nowo zarejestrowanymi bezrobotnymi obniżył się z 4647 osób do 1714 osób, a w 2009 r. wzrósł do 2115 osób; nie pokazuje więc sytuacji już tak optymistycznie. Można obliczyć, że każdemu nowo zarejestrowanemu bezrobotnemu doradca mógłby poświęcić około 45 minut. W rzeczywistości ten potencjalny czas jest krótszy, bowiem w rachunku nie uwzględniono poszukujących pracy, a także innych zadań doradcy zawodowego. Usługi doradztwa zawodowego świadczone są głównie bezrobotnym, którzy stanowią ponad $90 \%$ korzystających.

W okresie 2005-2009 liczba bezrobotnych korzystających z poradnictwa indywidualnego wzrosła o połowę, a korzystających z grupowej informacji zawodowej o ponad 70\%. Zmalała natomiast liczba osób korzystających z poradnictwa grupowego (o 42\%) i badań testowych (o 21\%). Niepokojący jest natomiast spadek liczby bezrobotnych korzystających z poradnictwa indywidualnego przypadających na jednego doradcę z 374 osób w 2005 r. do 261 bezrobotnych w 2009 r. Doradztwo zawodowe jest procesem wymagającym szeregu spotkań bezrobotnego $\mathrm{z}$ doradcą zawodowym. Być może więc zmniejszenie obciążenia doradców zawodowych liczbą bezrobotnych korzystających z porad spowodowało znaczny wzrost jakości świadczonych usług. Trudno ten fakt stwierdzić. 
Jednak liczba porad przypadających na bezrobotnego korzystającego z doradztwa indywidualnego nie uległa zmianie i wynosiła około 1,35. Oznacza to, że co najwyżej jedna trzecia bezrobotnych uczestniczyła w poradzie udzielanej w powiatowym urzędzie pracy częściej niż jeden raz.

Tabela 4. Bezrobotni korzystający z usług poradnictwa zawodowego w Polsce w latach 2005-2009 (w tys.)

\begin{tabular}{|c|c|c|c|c|c|c|}
\hline \multirow{2}{*}{ Lata } & \multicolumn{4}{|c|}{ Poradnictwo zawodowe } & \multicolumn{2}{c|}{ Informacja zawodowa } \\
\cline { 2 - 7 } & \multicolumn{2}{|c|}{ indywidualne } & grupowe & $\begin{array}{c}\text { badania } \\
\text { testowe }\end{array}$ & indywidualna & grupowa \\
\cline { 2 - 7 } & liczba wizyt & \multicolumn{3}{|c|}{ liczba osób } & liczba wizyt & liczba osób \\
\hline 2005 & 395,6 & 292,7 & 134,3 & 31,7 &. & 133,3 \\
\hline 2006 & 398,0 & 296,0 & 114,6 & 17,0 &. & 121,0 \\
\hline 2007 & 408,8 & 312,8 & 81,3 & 9,8 &. & 116,9 \\
\hline 2008 & 504,5 & 374,5 & 74,0 & 11,5 &. & 144,9 \\
\hline 2009 & 586,7 & 434,7 & 77,6 & 25,1 &. & 227,8 \\
\hline
\end{tabular}

Źródło: Informacja o realizacji ustug poradnictwa zawodowego $w$ urzędach pracy $w 2005$ roku, MPiPS, Departament Rynku Pracy, Warszawa 2006; Informacja o realizacji ustug poradnictwa zawodowego w urzędach pracy w 2006 roku, MPiPS, Departament Rynku Pracy, Warszawa 2007; Informacja o realizacji ustug poradnictwa zawodowego $w$ urzędach pracy $w 2007$ roku, MPiPS, Departament Rynku Pracy, Warszawa 2008; Informacja o realizacji ustug poradnictwa zawodowego w urzędach pracy w 2008 roku, MPiPS, Departament Rynku Pracy, Warszawa 2009; Bezrobocie w Polsce w 2009 r. Raport tabelaryczny, MPiPS, Departament Rynku Pracy, Warszawa 2010.

Bezrobotni objęci różnymi formami poradnictwa zawodowego stanowili w 2008 r. około 31\% ogółu bezrobotnych figurujących w rejestracji w końcu tego roku, oraz 18,6\% bezrobotnych nowo zarejestrowanych w tym roku. W 2009 r., wskutek wzrostu poziomu bezrobocia, odpowiednie wskaźniki obniżyły się do 28,4\% i 17,4\%. Dane statystyczne za lata 2008 i 2009 informują o liczbie bezrobotnych, którzy skorzystali z rozmowy wstępnej z doradcą zawodowym. Stanowili oni około $10 \%$ bezrobotnych nowo zarejestrowanych w 2008 r. i $14,9 \%$ nowo zarejestrowanych bezrobotnych w 2009 r. Jednak struktura bezrobotnych korzystających z rozmowy wstępnej według okresu trwania bezrobocia pokazała, że około 50\% pozostawało w rejestrach krócej niż 6 miesięcy, kilkanaście procent przez okres 6-12 miesięcy i aż 36\% w 2008 r. i 31\% w 2009 r. dłużej niż rok. Oznacza to, że z rozmowy wstępnej z doradcą zawodowym skorzystało co najwyżej 6,5\% bezrobotnych nowo pojawiających się w rejestracji w $2008 \mathrm{r}$. i 10,3\% w 2009 r. Wskazuje to, że doradztwo zawodowe w zbyt małym stopniu i zbyt późno włączane jest $\mathrm{w}$ proces walki z bezrobociem. 
Tabela 5. Efekty usług poradnictwa zawodowego świadczonych bezrobotnym w pup w Polsce w latach 2005-2009 (w tys.)

\begin{tabular}{|c|c|c|c|c|c|c|c|c|c|}
\hline \multirow{2}{*}{ Lata } & \multirow{2}{*}{$\begin{array}{c}\text { Liczba } \\
\text { korzysta- } \\
\text { jących }\end{array}$} & \multicolumn{2}{|c|}{ Podjęcie pracy } & \multicolumn{2}{c|}{$\begin{array}{c}\text { Szkolenie } \\
\text { zawodowe }\end{array}$} & \multicolumn{2}{c|}{$\begin{array}{c}\text { Pomoc w aktywnym } \\
\text { poszukiwaniu pracy }\end{array}$} & \multicolumn{2}{|c|}{$\begin{array}{c}\text { Skierowanie do } \\
\text { CliPKZ }\end{array}$} \\
\cline { 3 - 11 } & liczba & $\%$ & liczba & $\%$ & liczba & $\%$ & liczba & $\%$ \\
\hline 2005 & 375,5 & 72,6 & 19,3 & 86,9 & 23,1 & 19,2 & 5,1 & 2,0 & 0,5 \\
\hline 2006 & 281,0 & 66,2 & 23,6 & 76,6 & 27,3 & 16,7 & 5,9 & 1,6 & 0,6 \\
\hline 2007 & 301,5 & 99,2 & 32,9 & 86,4 & 28,7 & 15,2 & 5,0 & 2,4 & 0,8 \\
\hline 2008 & 367,7 & 98,7 & 26,8 & 67,6 & 18,4 & 17,1 & 4,7 & 1,1 & 0,3 \\
\hline 2009 & 425,6 & 91,3 & 21,5 & 61,3 & 14,4 & 23,2 & 5,5 & 1,4 & 0,3 \\
\hline
\end{tabular}

Źródło: Informacja o realizacji usług poradnictwa zawodowego $w$ urzędach pracy $w 2005$ roku, MPiPS, Departament Rynku Pracy, Warszawa 2006; Informacja o realizacji ustug poradnictwa zawodowego w urzędach pracy w 2006 roku, MPiPS, Departament Rynku Pracy, Warszawa 2007; Informacja o realizacji ustug poradnictwa zawodowego w urzędach pracy w 2007 roku, MPiPS, Departament Rynku Pracy, Warszawa 2008; Informacja o realizacji ustug poradnictwa zawodowego w urzędach pracy w 2008 roku, MPiPS, Departament Rynku Pracy, Warszawa 2009; Bezrobocie w Polsce w 2009 r. Raport tabelaryczny, MPiPS, Departament Rynku Pracy, Warszawa 2010.

Statystyki efektów usług poradnictwa zawodowego świadczonych bezrobotnym pokazują, że mniej więcej co czwarty bezrobotny z nich korzystający podejmował w ciągu trzech miesięcy pracę, na szkolenie zawodowe kierowano na początku badanego okresu około $25 \%$, a w końcu już tylko około $14 \%$, do klubów pracy około 5\% i do CliPKZ 0,5\%. Brakuje informacji o efektach w stosunku do ponad połowy osób bezrobotnych, którym udzielono porady, co mogłoby świadczyć o swoistej niemocy publicznych służb zatrudnienia w stosunku do bezrobotnych. Jednak statystyki MPiPS umożliwiają ustalenie efektów tylko w postaci podjęcia pracy i udziału w wybranych usługach rynku pracy, natomiast nie jest możliwa identyfikacja na ich podstawie innych wygenerowanych w wyniku poradnictwa zawodowego działań (które w PUP są podejmowane).

Skuteczność usług świadczonych przez poradnictwo zawodowe trzeba ocenić jako niską, a zakres osób nimi objętych jest stanowczo zbyt mały w stosunku do występujących potencjalnie potrzeb. Ocena ta nie dotyczy oczywiście jakości każdej świadczonej indywidualnie przez doradcę zawodowego usługi. Tym niemniej, oceniając poradnictwo zawodowe jako całość na tle występujących potencjalnie potrzeb i odnosząc do rozmiarów populacji bezrobotnych nie można ocenić jego jakości wysoko. Ze względów wskazanych przy omawianiu usług pośrednictwa pracy nie można również ocenić efektywności kosztowej poradnictwa i informacji zawodowej.

Pomoc w aktywnym poszukiwaniu pracy świadczona bezrobotnym i poszukującym pracy polega na przygotowywaniu bezrobotnych i poszukujących pracy do lepszego radzenia sobie $\mathrm{w}$ poszukiwaniu i podejmowaniu zatrudnienia. 
Odbywa się w trzech formach: szkoleń z zakresu umiejętności poszukiwania pracy, zajęć aktywizacyjnych oraz umożliwienia dostępu do informacji elektronicznych i baz danych służących uzyskaniu umiejętności poszukiwania pracy i samozatrudnienia.

Liczba uczestników szkoleń i zajęć aktywizacyjnych (znacznie ponad 90\% uczestników stanowili bezrobotni) wykazywała tendencję malejącą do $2007 \mathrm{r}$. W następnych latach wzrosła, co było zapewne efektem przyrostu liczby zatrudnionych liderów klubów pracy. Liczba osób objętych działaniami klubów pracy w przeliczeniu na klub nie była wysoka i zmalała ze 135 osób w 2005 r. do 81 osób w 2008 r., a w następnym roku zwiększyła się do 117 osób. Szczególnie niewielka była liczba osób w poszczególnych klubach objętych szkoleniami w zakresie aktywnego poszukiwania pracy; zmalała z 26 w 2005 r. do 15,7 w 2008 r., a następnie wzrosła do 18,8 osób w 2009 r. Oznacza to, że w 2005 r. w klubie organizowano przeciętnie dwie grupy szkoleniowe rocznie, a w latach 2008-2009 przeciętnie nieco ponad jedną.

Tabela 6. Pomoc w aktywnym poszukiwaniu pracy w Polsce w latach 2005-2009

\begin{tabular}{|c|c|c|c|c|c|c|}
\hline \multirow{2}{*}{ Lata } & \multicolumn{2}{|c|}{ Liczba klubów pracy } & \multicolumn{2}{c|}{ Liczba uczestników szkoleń } & \multicolumn{2}{c|}{$\begin{array}{c}\text { Liczba uczestników zajęć } \\
\text { aktywizacyjnych }\end{array}$} \\
\cline { 2 - 7 } & ogółem & $\begin{array}{c}\text { prowadzone } \\
\text { przez pup }\end{array}$ & ogółem & bezrobotni & ogółem & bezrobotni \\
\hline 2005 & 588 & 477 & 15397 & 14162 & 63862 & 60611 \\
\hline 2006 & 611 & 525 & 11568 & 10977 & 64193 & 59001 \\
\hline 2007 & 629 & 549 & 9548 & 8854 & 57988 & 52669 \\
\hline 2008 & 923 & 846 & 14579 & 14218 & 60251 & 56315 \\
\hline 2009 & 1059 & 1000 & 19947 & 19687 & 104125 & 99932 \\
\hline
\end{tabular}

Źródło: Informacja o realizacji usługi - pomoc $w$ aktywnym poszukiwaniu pracy $w 2005$ roku, MPiPS, Departament Rynku Pracy, Warszawa 2006; Informacja o realizacji ustugi-pomoc w aktywnym poszukiwaniu pracy w 2006 roku, MPiPS, Departament Rynku Pracy, Warszawa 2007; Informacja o realizacji ustugi - pomoc $w$ aktywnym poszukiwaniu pracy $w 2007$ roku, MPiPS, Departament Rynku Pracy, Warszawa 2008; Informacja o realizacji ustugi-pomoc w aktywnym poszukiwaniu pracy w 2008 roku, MPiPS, Departament Rynku Pracy, Warszawa 2009; Bezrobocie w Polsce w 2009 r. Raport tabelaryczny, MPiPS, Departament Rynku Pracy, Warszawa 2010.

Usługi świadczone bezrobotnym i poszukującym pracy w zakresie pomocy w aktywnym poszukiwaniu pracy są niezwykle pożyteczne, dają praktyczne umiejętności przygotowania dokumentów rekrutacyjnych, przygotowania się do rozmowy rekrutacyjnej, wzmacniają wiarę w siebie i w konsekwencji pewność siebie, podnoszą motywację do poszukiwania pracy. Powinny więc obejmować znaczną liczbę bezrobotnych i być skorelowane $\mathrm{z}$ wykorzystywaniem innych instrumentów rynku pracy. Tymczasem dotyczą zaledwie niewielkiej ich części (w 2008 r. około 4\%, w 2009 r. nieco ponad 6\%). 
Tabela 7. Efektywność usługi - pomoc w aktywnym poszukiwaniu pracy w Polsce w latach 2005-2009

\begin{tabular}{|c|c|c|c|c|c|c|c|c|}
\hline \multirow{3}{*}{ Lata } & \multicolumn{8}{|c|}{ Osoby które } \\
\hline & \multicolumn{2}{|c|}{$\begin{array}{l}\text { rozpoczęły udział } \\
\text { w programie }\end{array}$} & \multicolumn{2}{|c|}{ ukończyły program } & \multicolumn{2}{|c|}{$\begin{array}{c}\text { podjęły pracę w trakcie } \\
\text { lub po zakończeniu } \\
\text { zajęć }\end{array}$} & \multicolumn{2}{|c|}{$\begin{array}{c}\text { rozpoczęły szkolenie } \\
\text { zawodowe w trakcie } \\
\text { lub po zakończeniu } \\
\text { zajęć }\end{array}$} \\
\hline & ogółem & bezrobotni & ogółem & bezrobotni & ogółem & bezrobotni & ogółem & bezrobotni \\
\hline \multicolumn{9}{|c|}{ szkolenia w klubach pracy w zakresie aktywnego poszukiwania pracy } \\
\hline 2005 & 14610 & 13385 & 12278 & 11358 & 2276 & 2263 & 3903 & 3723 \\
\hline 2006 & 12148 & 11534 & 11075 & 10521 & 2749 & 2732 & 1342 & 1336 \\
\hline 2007 & 9554 & 8896 & 9047 & 8409 & 2248 & 2172 & 903 & 897 \\
\hline 2008 & 14470 & 14273 & 13789 & 13624 & 5543 & 5497 & 1912 & 1897 \\
\hline 2009 & 20229 & 19972 & 18955 & 18760 & 2517 & 2512 & 1767 & 1761 \\
\hline \multicolumn{9}{|c|}{ zajęcia aktywizacyjne } \\
\hline 2005 & . & . & 63795 & 60576 & 9761 & 9695 & 7294 & 7112 \\
\hline 2006 & . & . & 64186 & 58786 & 13838 & 13617 & 5982 & 5936 \\
\hline 2007 & . & . & 58061 & 52713 & 15511 & 15431 & 5919 & 5864 \\
\hline 2008 & 52400 & 48289 & 59029 & 54770 & 11245 & 11203 & 4064 & 4021 \\
\hline 2009 & 99737 & 96921 & 99384 & 96644 & 14426 & 14285 & 4120 & 4082 \\
\hline
\end{tabular}

Źródło: Informacja o realizacji usługi - pomoc $w$ aktywnym poszukiwaniu pracy $w 2005$ roku, MPiPS, Departament Rynku Pracy, Warszawa 2006; Informacja o realizacji ustugi-pomoc w aktywnym poszukiwaniu pracy w 2006 roku, MPiPS, Departament Rynku Pracy, Warszawa 2007; Informacja o realizacji ustugi - pomoc $w$ aktywnym poszukiwaniu pracy $w 2007$ roku, MPiPS, Departament Rynku Pracy, Warszawa 2008; Informacja o realizacji ustugi - pomoc w aktywnym poszukiwaniu pracy w 2008 roku, MPiPS, Departament Rynku Pracy, Warszawa 2009; Bezrobocie w Polsce w 2009 r. Raport tabelaryczny, MPiPS, Departament Rynku Pracy, Warszawa 2010.

Wydatkowany wysiłek organizacyjny związany $z$ tworzeniem i wyposażeniem klubów pracy, a także podejmowane działania kadrowe budzą nadzieję i oczekiwania na znacznie lepsze rezultaty. Efektywność zatrudnieniowa szkoleń aktywizacyjnych, wynosząca w latach 2005-2007 około 20-25\% wzrosła w 2008 r. do wysokiego poziomu 40\%, ale w 2009 r. ponownie obniżyła się do nieco ponad $13 \%$. Działania aktywizacyjne owocują znalezieniem zatrudnienia przez około $20 \%$ osób w nich uczestniczących, jednak w 2009 r. zatrudnienie w ich wyniku podjęło nieco mniej niż 15\%. Zmniejszenie efektywności zatrudnieniowej pomocy w aktywnym poszukiwaniu pracy w 2009 r. wynikało zapewne z pogorszenia sytuacji na rynku pracy. Gdyby można przyjąć, że jest to efekt netto świadczenia tej usługi, wówczas, mimo wszystko, należałoby ocenić go wysoko. 


\section{POZOSTAŁE AKTYWNE PROGRAMY RYNKU PRACY}

Wydatki na aktywne programy finansowane z Funduszu Pracy wykazywały tendencję wzrostową. W 2009 r. wyniosły 4,0 mld zł i były o $115 \%$ większe niż w 2005 r. Tempo wzrostu wydatków na aktywne programy rynku pracy wyprzedzało tempo wzrostu wydatków z Funduszu Pracy ogółem i było znacznie wyższe niż stopa inflacji. Udział wydatków na aktywne programy rynku pracy w wydatkach z Funduszu Pracy wzrósł z 33,7\% w 2005 r. do 54,1\% w 2008 r., a w roku następnym obniżył się do 35,7\%. Spadek udziału tych wydatków wynikał ze znacznego zwiększenia w 2009 r. wydatków z Funduszu Pracy ogółem oraz z przeznaczenia dużych środków na tzw. pozostałe programy przeciwdziałania bezrobociu, których udział wyniósł niemal 11\% (w poprzednich latach było to $0,5-1,7 \%$ ) i inne cele podnoszące jakość kapitału ludzkiego i ograniczające bezrobocie.

Tabela 8. Wydatki z Funduszu Pracy na aktywne programy rynku pracy w Polsce w latach 2005-2009

\begin{tabular}{|c|c|c|c|c|c|c|c|c|c|}
\hline 丞 & 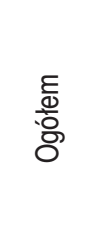 & 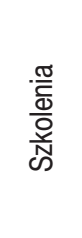 & d: & $\begin{array}{l}\frac{0}{N} \\
\frac{0}{0} \\
\frac{0}{2} \\
\frac{2}{0} \\
\frac{0}{0} \\
\propto x\end{array}$ & 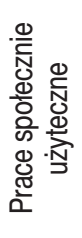 & $\begin{array}{l}\text { त्ञ } \\
\text { ஸँ }\end{array}$ & 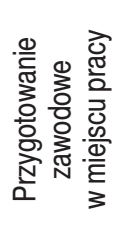 & 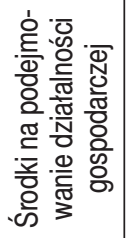 & 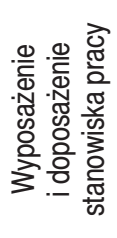 \\
\hline \multicolumn{10}{|c|}{ w mln zł } \\
\hline 2005 & 1870,0 & 181,8 & 193,9 & 294,3 & $x$ & 600,7 & 193,6 & \multicolumn{2}{|c|}{405,7} \\
\hline 2006 & 2029,0 & 186,7 & 220,0 & 145,6 & 25,6 & 671,9 & 203,1 & 373,4 & 200,6 \\
\hline 2007 & 2493,3 & 266,3 & 214,7 & 178,0 & 33,2 & 693,4 & 214,7 & 536,7 & 361,3 \\
\hline 2008 & 3110,8 & 280,1 & 196,5 & 248,4 & 33,9 & 919,4 & 350,0 & 699,0 & 383,4 \\
\hline 2009 & 4015,7 & 379,7 & 180,5 & 329,5 & 36,7 & 1352,3 & 128,5 & 1093,9 & 514,6 \\
\hline \multicolumn{10}{|c|}{$\mathrm{w} \%$} \\
\hline 2005 & 100,0 & 9,7 & 10,4 & 15,7 & $\mathrm{x}$ & 32,1 & 10,4 & \multicolumn{2}{|c|}{21,7} \\
\hline 2006 & 100,0 & 9,2 & 10,8 & 7,2 & 1,3 & 33,1 & 10,0 & 18,4 & 9,9 \\
\hline 2007 & 100,0 & 10,7 & 8,6 & 7,1 & 1,3 & 27,8 & 8,6 & 21,5 & 14,5 \\
\hline 2008 & 100,0 & 9,0 & 6,3 & 8,0 & 1,1 & 29,6 & 11,3 & 22,5 & 12,3 \\
\hline 2009 & 100,0 & 9,5 & 4,5 & 8,2 & 0,9 & 33,7 & 3,2 & 27,2 & 12,8 \\
\hline
\end{tabular}

Źródło: Polska 2006. Raport o rynku pracy oraz zabezpieczeniu społecznym 2006, MPiPS, Warszawa 2006; Efektywność podstawowych form promocji zatrudnienia i aktywizacji zawodowej bezrobotnych finansowanych z Funduszu Pracy w 2007 r., MPiPS Departament Funduszy, Warszawa wrzesień 2008; Efektywność podstawowych form promocji zatrudnienia i aktywizacji zawodowej bezrobotnych finansowanych z Funduszu Pracy w 2008 r., MPiPS Departament Funduszy, Warszawa sierpień 2009; Efektywność podstawowych form aktywizacji zawodowej realizowanych $w$ ramach programów na rzecz promocji zatrudnienia, łagodzenia skutków bezrobocia i aktywizacji zawodowej w 2009 r., Warszawa, lipiec 2010. 
Dynamika wzrostu wydatków na poszczególne programy aktywne była zróżnicowana, co doprowadziło do znacznych zmian w strukturze wydatków. Najszybciej wzrosły wydatki na dotowanie podejmowania działalności gospodarczej i wyposażenia i doposażenia stanowisk pracy, staże i szkolenia, w znacznie mniejszym stopniu na prace społecznie użyteczne i roboty publiczne, a obniżeniu uległy wydatki na prace interwencyjne i przygotowanie zawodowe w miejscu pracy (w tym ostatnim przypadku wynikało to z likwidacji instrumentu i zakończenia wykorzystywania go w 2009 r.). W konsekwencji udział wydatków na dotowanie działalności gospodarczej i tworzenie miejsc pracy wzrósł z 21,7\% do 40,0\%, udział wydatków na staże wzrósł o 1,6 punktu procentowego (ale dotyczyło to instrumentu o znacznie poszerzonym od 2009 r. zakresie podmiotowym), a szkolenia utrzymały swoją pozycję z udziałem rzędu 9-10\%. Zmalał

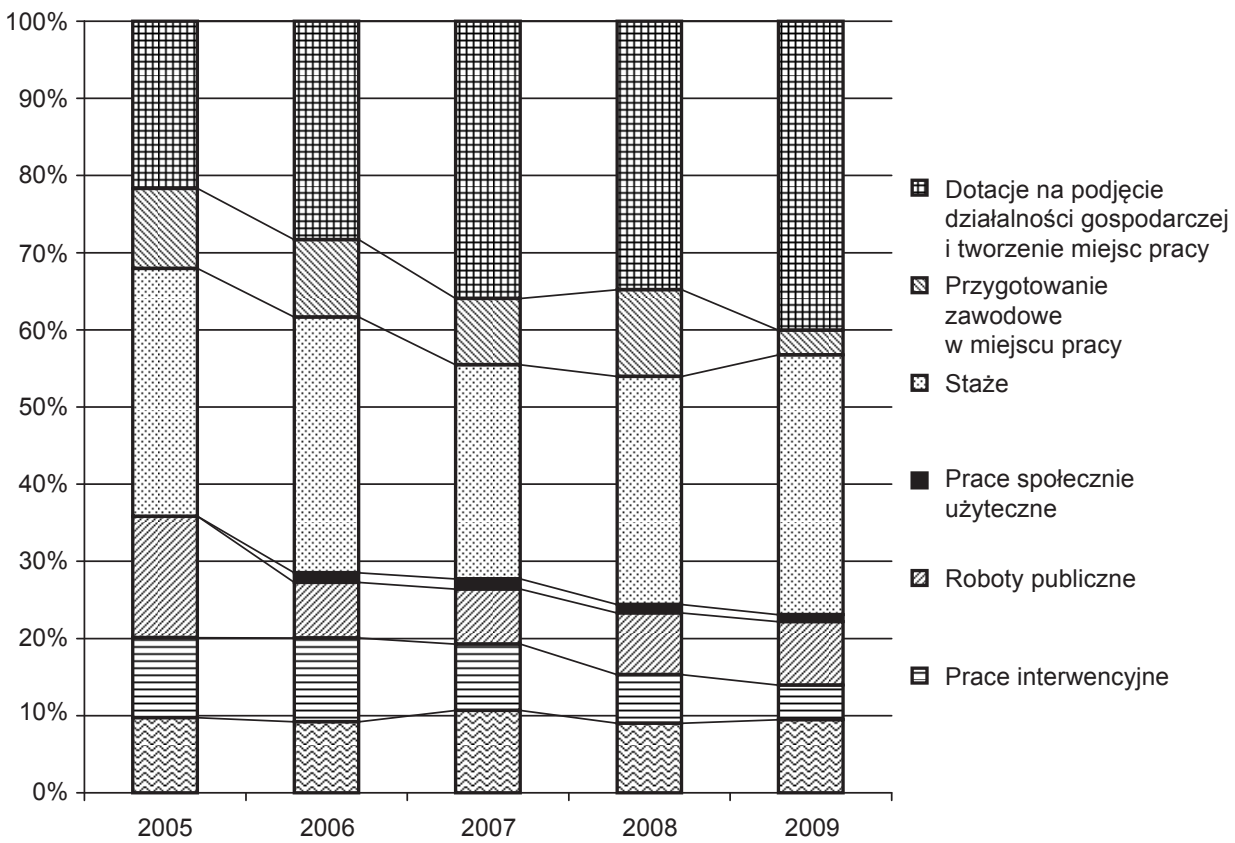

Wykres 1 . Struktura wydatków z Funduszu Pracy na aktywne programy rynku pracy w Polsce w latach 2005-2009

Źródło: Polska 2006. Raport o rynku pracy oraz zabezpieczeniu społecznym 2006, MPiPS, Warszawa 2006; Efektywność podstawowych form promocji zatrudnienia i aktywizacji zawodowej bezrobotnych finansowanych z Funduszu Pracy w 2007 r., MPiPS Departament Funduszy, Warszawa wrzesień 2008; Efektywność podstawowych form promocji zatrudnienia i aktywizacji zawodowej bezrobotnych finansowanych z Funduszu Pracy w 2008 r., MPiPS Departament Funduszy, Warszawa sierpień 2009; Efektywność podstawowych form aktywizacji zawodowej realizowanych w ramach programów na rzecz promocji zatrudnienia, lagodzenia skutków bezrobocia i aktywizacji zawodowej w 2009 r., Warszawa, lipiec 2010. 
natomiast udział wydatków na pozostałe programy, najbardziej (nie licząc likwidowanego przygotowania zawodowego w miejscu pracy) na prace interwencyjne (o prawie 60\%).

Liczba bezrobotnych uczestniczących w aktywnych programach rynku pracy wzrosła w omawianym okresie o około $22 \%$, przy spadku liczby bezrobotnych w tym samym okresie o około 37\%. Tak więc zakres bezrobotnych, którzy weszli w orbitę oddziaływania programów aktywnych znacznie się rozszerzył. Ponad 95\% osób rozpoczynających udział w programie kończyło go. Najmniejsza sprawność cechowała staże i przygotowanie zawodowe w miejscu pracy, ale mogło wynikać to z długości okresu ich trwania i podejmowania przez bezrobotnych w ich trakcie pracy.

Największą ekspansją charakteryzowało się podejmowanie działalności gospodarczej oraz tworzenie miejsc pracy, liczba bezrobotnych korzystających z tych programów zwiększyła się ponad dwukrotnie. O prawie $60 \%$ wzrosła liczba bezrobotnych uczestniczących w stażach i niemal o $12 \%$ liczba korzystających ze szkoleń. Zmalała natomiast liczba bezrobotnych uczestniczących w pracach interwencyjnych (o 43\%) i w robotach publicznych (o 22\%). Spadek udziału zatrudnianych w ramach prac interwencyjnych wiąże się z dość rygorystycznymi warunkami związanymi z koniecznością zatrudnienia bezrobotnego po zakończeniu prac interwencyjnych. Korzystniejsze warunki stwarzały staże, a po zmianach ustawy w końcu 2008 r., kiedy rozszerzono ich zakres podmiotowy, stały się jeszcze bardziej atrakcyjne.

W strukturze osób bezrobotnych uczestniczących i kończących poszczególne aktywne programy rynku pracy największy udział mają staże. Ich udział wśród kończących program zwiększył się z 27\% do 32\%. Drugie miejsce zajmują szkolenia, ale ich udział wykazywał tendencję malejącą, obniżył się z $29 \%$ do $25 \%$. Zmalał również niemal o połową udział prac interwencyjnych i robót publicznych. Wzrósł natomiast udział dotacji na podejmowanie działalności gospodarczej i tworzenie miejsc pracy z $8 \%$ do $14 \%$. Występuje duża nierównomierność w rozdziale środków z Funduszu Pracy między programy aktywne. Mające 14\% uczestników dotacje pochłaniają 40\% wydatków z Funduszu Pracy, natomiast szkolenia, partycypujące w liczbie uczestników w $25 \%$ pochłaniają poniżej $10 \%$ wydatków na programy aktywne (zob. tabela 9).

Efektywność zatrudnieniowa aktywnych programów rynku pracy kształtuje się na poziomie powyżej 50\%, rośnie wówczas, kiedy sytuacja na rynku pracy poprawia się, a maleje kiedy ulega pogorszeniu. Największa efektywność zatrudnieniowa cechuje dotacje na podejmowanie działalności gospodarczej i tworzenie stanowisk pracy; wynosi $100 \%$. Poziom ten wynika ze sposobu badania efektywności zatrudnieniowej ( 3 miesiące po zakończeniu uczestnictwa w programie) i jest na pewno zawyżony, ale trudno wnioskować o skali tego zawyżenia. 
Tabela 9. Uczestnicy aktywnych programów rynku pracy w Polsce w latach 2005-2009

\begin{tabular}{|c|c|c|c|c|c|c|c|c|c|}
\hline$\stackrel{\widetilde{\Xi}}{\Xi}$ & $\begin{array}{l}\frac{E}{\omega} \\
\frac{0}{0} \\
0\end{array}$ & 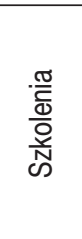 & 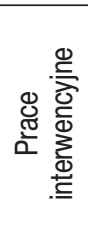 & 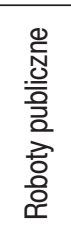 & 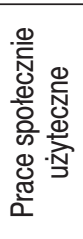 & 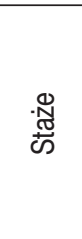 & 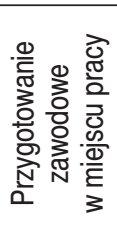 & 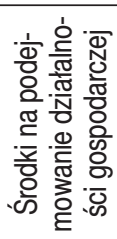 & 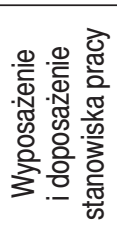 \\
\hline \multicolumn{10}{|c|}{ Liczba uczestników programu w tys. } \\
\hline 2005 & 561,7 & 150,7 & 70,9 & 69,2 & $x$ & 162,7 & 67,0 & 27,9 & 13,1 \\
\hline 2006 & 594,3 & 146,9 & 69,1 & 32,7 & 61,5 & 169,1 & 58,3 & 34,9 & 21,8 \\
\hline 2007 & 672,8 & 178,1 & 59,1 & 40,9 & 73,4 & 173,0 & 65,8 & 45,1 & 37,4 \\
\hline 2008 & 652,3 & 168,3 & 46,0 & 44,5 & 63,9 & 169,9 & 79,4 & 52,2 & 28,0 \\
\hline 2009 & 684,6 & 168,3 & 40,3 & 54,0 & 65,8 & 256,7 & 7,2 & 63,9 & 28,4 \\
\hline \multicolumn{10}{|c|}{ Liczba osób, które ukończyły program w tys. } \\
\hline 2005 & 501,8 & 147,6 & 60,5 & 68,1 & $\mathrm{x}$ & 135,6 & 48,6 & 27,9 & 13,1 \\
\hline 2006 & 567,7 & 142,1 & 62,5 & 34,7 & 56,9 & 155,6 & 59,2 & 34,9 & 21,8 \\
\hline 2007 & 647,9 & 172,4 & 56,4 & 37,7 & 72,5 & 164,5 & 61,3 & 45,1 & 37,4 \\
\hline 2008 & 607,4 & 163,3 & 46,7 & 42,4 & 61,2 & 150,0 & 63,7 & 52,2 & 28,0 \\
\hline 2009 & 651,2 & 163,7 & 39,2 & 52,3 & 64,8 & 208,9 & 30,0 & 63,9 & 28,4 \\
\hline \multicolumn{10}{|c|}{ Liczba osób zatrudnionych po uczestnictwie w programie w tys. } \\
\hline 2005 & 237,6 & 54,9 & 40,1 & 19,8 & $\mathrm{x}$ & 62,9 & 22,6 & 27,9 & 13,1 \\
\hline 2006 & 311,6 & 64,1 & 45,2 & 16,0 & 19,9 & 79,4 & 30,2 & 34,9 & 21,8 \\
\hline 2007 & 374,0 & 76,6 & 42,0 & 17,7 & 31,9 & 91,1 & 32,2 & 45,1 & 37,4 \\
\hline 2008 & 340,1 & 64,0 & 34,2 & 19,8 & 26,6 & 81,3 & 34,0 & 52,2 & 28,0 \\
\hline 2009 & 346,5 & 56,2 & 28,1 & 25,1 & 25,8 & 103,3 & 15,6 & 63,9 & 28,4 \\
\hline
\end{tabular}

Źródło: Polska 2006. Raport o rynku pracy oraz zabezpieczeniu społecznym 2006, MPiPS, Warszawa 2006; Efektywność podstawowych form promocji zatrudnienia i aktywizacji zawodowej bezrobotnych finansowanych z Funduszu Pracy w 2007 r., MPiPS Departament Funduszy, Warszawa wrzesien 2008; Efektywność podstawowych form promocji zatrudnienia i aktywizacji zawodowej bezrobotnych finansowanych z Funduszu Pracy w 2008 r., MPiPS Departament Funduszy, Warszawa sierpień 2009; Efektywność podstawowych form aktywizacji zawodowej realizowanych w ramach programów na rzecz promocji zatrudnienia, łagodzenia skutków bezrobocia i aktywizacji zawodowej w 2009 r., Warszawa, lipiec 2010.

Dużą efektywnością zatrudnieniową charakteryzują się prace interwencyjne (ponad $70 \%$ ), ale jest ona wymuszona przez przepisy dotyczące pomocy publicznej dla przedsiębiorstw. Jest to prawdopodobnie czynnik, który wpływa na spadek zainteresowania pracodawców tym instrumentem. Mniej więcej co druga osoba kończąca staż lub przygotowanie zawodowe w miejscu pracy znajduje zatrudnienie. Najmniejszą natomiast efektywność zatrudnieniową posiadają szkolenia; zmalała ona w ostatnich latach do około $34 \%$.

Przeciętny koszt uczestnictwa bezrobotnego w programie wzrósł w latach 2005-2009 z 3317 zł do 5866 zł, to jest o 77\%. Szybciej od przeciętnego rósł jedynie koszt uczestnictwa w szkoleniach (o 95\%). Kosztochłonność poszczególnych 
programów była zróżnicowana. Najdroższe były dotacje na podjęcie działalności gospodarczej i tworzenie stanowisk pracy; kosztowały ośmiokrotnie więcej niż szkolenia. Kosztowne były również roboty publiczne i staże, ich koszty ponad trzykrotnie przewyższały koszty szkoleń, natomiast jednostkowe koszty uczestnictwa $\mathrm{w}$ robotach publicznych i przygotowaniu zawodowym $\mathrm{w}$ miejscu pracy były około 2,5 razy wyższe od kosztów uczestnictwa w szkoleniach ${ }^{1}$.

Tabela 10. Efektywność zatrudnieniowa i kosztowa aktywnych programów rynku pracy w Polsce w latach 2005-2009

\begin{tabular}{|c|c|c|c|c|c|c|c|c|c|}
\hline 苛 & $\frac{\mathrm{E}}{\frac{0}{0}}$ & 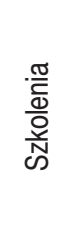 & 竞 & 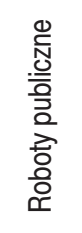 & 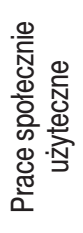 & $\begin{array}{l}\text { त्ञ } \\
\text { đू }\end{array}$ & 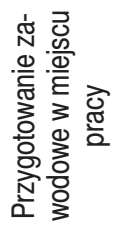 & 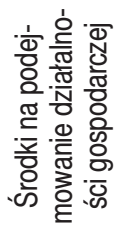 & 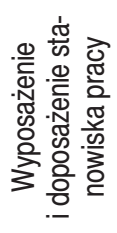 \\
\hline \multicolumn{10}{|c|}{ Efektywność zatrudnieniowa w\% } \\
\hline 2005 & 47,3 & 37,2 & 66,3 & 29,0 & $\mathrm{x}$ & 46,3 & 46,5 & 100,0 & 100,0 \\
\hline 2006 & 54,9 & 45,1 & 72,2 & 46,0 & 35,0 & 51,1 & 51,1 & 100,0 & 100,0 \\
\hline 2007 & 57,7 & 44,4 & 74,3 & 46,9 & 44,0 & 55,2 & 52,6 & 100,0 & 100,0 \\
\hline 2008 & 56,0 & 39,2 & 73,4 & 46,6 & 43,4 & 54,2 & 53,4 & 100,0 & 100,0 \\
\hline 2009 & 53,2 & 34,3 & 71,8 & 48,0 & 39,8 & 49,5 & 52,0 & 100,0 & 100,0 \\
\hline \multicolumn{10}{|c|}{ Koszt uczestnictwa w programie w zł } \\
\hline 2005 & 3317 & 1157 & 2736 & 4254 & $\mathrm{x}$ & 3692 & 2891 & \multicolumn{2}{|c|}{12035} \\
\hline 2006 & 3414 & 1271 & 3186 & 4455 & 416 & 3973 & 3483 & 10700 & 9200 \\
\hline 2007 & 3713 & 1495 & 3633 & 4352 & 452 & 4008 & 3265 & 11904 & 9654 \\
\hline 2008 & 4769 & 1664 & 4268 & 5578 & 530 & 5413 & 4406 & 13402 & 13685 \\
\hline 2009 & 5866 & 2255 & 4475 & 6099 & 559 & 5269 & 17947 & 17102 & 18143 \\
\hline \multicolumn{10}{|c|}{ Koszt ponownego zatrudnienia w zł } \\
\hline 2005 & 7842 & 3173 & 4835 & 14884 & $\mathrm{x}$ & 9557 & 8567 & \multicolumn{2}{|c|}{12035} \\
\hline 2006 & 6511 & 2911 & 4869 & 9102 & 1285 & 8458 & 6720 & 10700 & 9200 \\
\hline 2007 & 6681 & 3477 & 5118 & 10050 & 1039 & 7615 & 6664 & 11904 & 9654 \\
\hline 2008 & 9148 & 4374 & 5737 & 12578 & 1277 & 11309 & 10299 & 13402 & 13685 \\
\hline 2009 & 11590 & 6762 & 6415 & 13122 & 1423 & 13085 & 8245 & 17102 & 18143 \\
\hline
\end{tabular}

Źródło: Polska 2006. Raport o rynku pracy oraz zabezpieczeniu społecznym 2006, MPiPS, Warszawa 2006; Efektywność podstawowych form promocji zatrudnienia i aktywizacji zawodowej bezrobotnych finansowanych z Funduszu Pracy w 2007 r., MPiPS Departament Funduszy, Warszawa wrzesień 2008; Efektywność podstawowych form promocji zatrudnienia i aktywizacji zawodowej bezrobotnych finansowanych z Funduszu Pracy w 2008 r., MPiPS Departament Funduszy, Warszawa sierpień 2009; Efektywność podstawowych form aktywizacji zawodowej realizowanych w ramach programów na rzecz promocji zatrudnienia, lagodzenia skutków bezrobocia i aktywizacji zawodowej w 2009 r., Warszawa, lipiec 2010.

$1 \quad$ W analizie pominięto prace społecznie użyteczne ze względu na niedoskonałość statystyki rynku pracy w tym zakresie i odmienny od innych cel tego programu, por. Z. Wiśniewski, K. Zawadzki (red.), op.cit., s. 82-83. 
Średni koszt ponownego zatrudnienia po skończeniu aktywnego programu rynku pracy wzrósł w badanym okresie z 7842 zł do 11590 zł, to jest o 48\%, czyli wolniej niż koszt uczestnictwa w programie, co wynikało ze wzrostu efektywności zatrudnieniowej tych programów. Jednocześnie można zaobserwować,

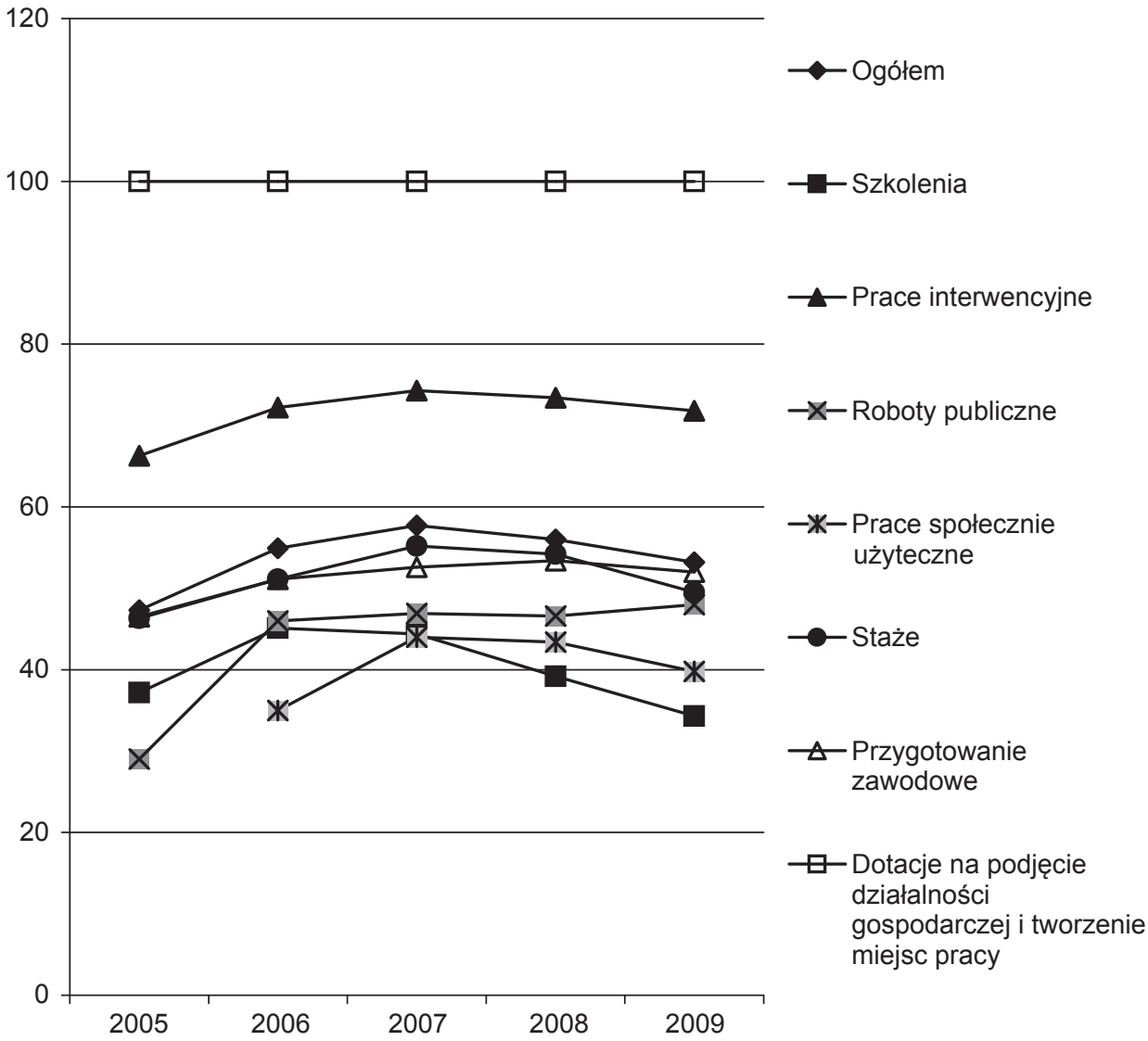

Wykres 2. Efektywność zatrudnieniowa aktywnych programów rynku pracy w Polsce w latach $2005-2009 \mathrm{w} \%$

Źródło: Polska 2006. Raport o rynku pracy oraz zabezpieczeniu społecznym 2006, MPiPS, Warszawa 2006; Efektywność podstawowych form promocji zatrudnienia i aktywizacji zawodowej bezrobotnych finansowanych z Funduszu Pracy w 2007 r., MPiPS Departament Funduszy, Warszawa wrzesień 2008; Efektywność podstawowych form promocji zatrudnienia i aktywizacji zawodowej bezrobotnych finansowanych z Funduszu Pracy w 2008 r., MPiPS Departament Funduszy, Warszawa sierpień 2009; Efektywność podstawowych form aktywizacji zawodowej realizowanych w ramach programów na rzecz promocji zatrudnienia, lagodzenia skutków bezrobocia i aktywizacji zawodowej w 2009 r., Warszawa, lipiec 2010. 
że najszybciej zwiększył się koszt ponownego zatrudnienia osób przeszkolonych, co było konsekwencją realizowania droższych programów szkoleniowych, obniżenia ich efektywności zatrudnieniowej i wyższych świadczeń dla uczestników szkoleń. Zróżnicowanie jednostkowego kosztu ponownego zatrudnienia

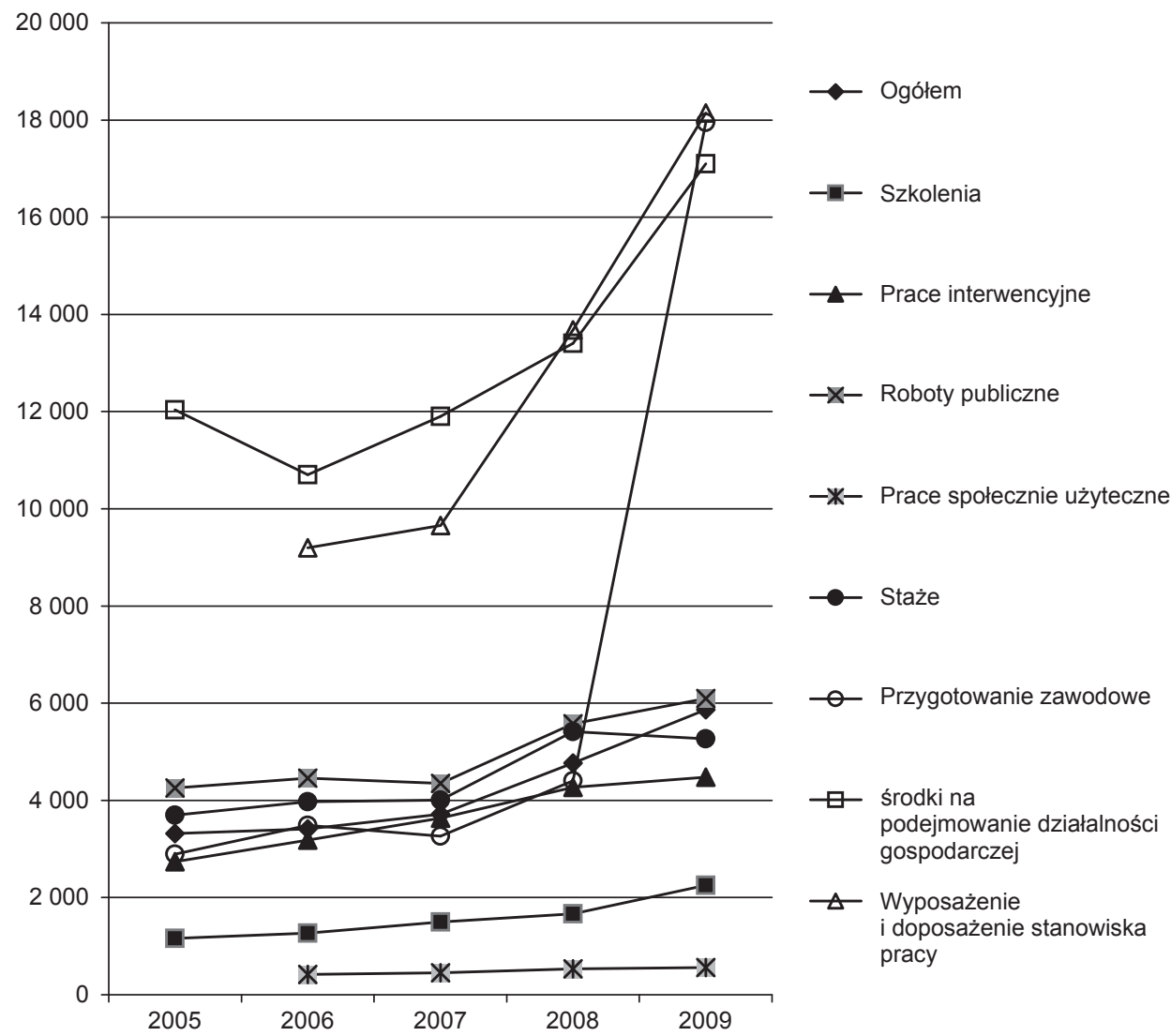

Wykres 3. Koszt uczestnictwa w aktywnych programach rynku pracy w Polsce w latach 2005-2009 w zł

Źródło: Polska 2006. Raport o rynku pracy oraz zabezpieczeniu społecznym 2006, MPiPS, Warszawa 2006; Efektywność podstawowych form promocji zatrudnienia i aktywizacji zawodowej bezrobotnych finansowanych z Funduszu Pracy w 2007 r., MPiPS Departament Funduszy, Warszawa wrzesień 2008; Efektywność podstawowych form promocji zatrudnienia i aktywizacji zawodowej bezrobotnych finansowanych z Funduszu Pracy w 2008 r., MPiPS Departament Funduszy, Warszawa sierpień 2009; Efektywność podstawowych form aktywizacji zawodowej realizowanych w ramach programów na rzecz promocji zatrudnienia, lagodzenia skutków bezrobocia i aktywizacji zawodowej w 2009 r., Warszawa, lipiec 2010. 
było znacznie mniejsze niż zróżnicowanie kosztów uczestnictwa w programie. Nadal najwyższy był koszt ponownego zatrudnienia po otrzymaniu dotacji na rozpoczęcie działalności gospodarczej i na tworzenie nowych stanowisk pracy, przewyższał on jednak tylko około trzykrotnie koszt ponownego zatrudnienia po szkoleniach. Relacje jednostkowych kosztów ponownego zatrudnienia w przypadku pozostałych programów i szkoleń były podobne do relacji zachodzących między kosztami uczestnictwa w szkoleniach i w pozostałych programach.

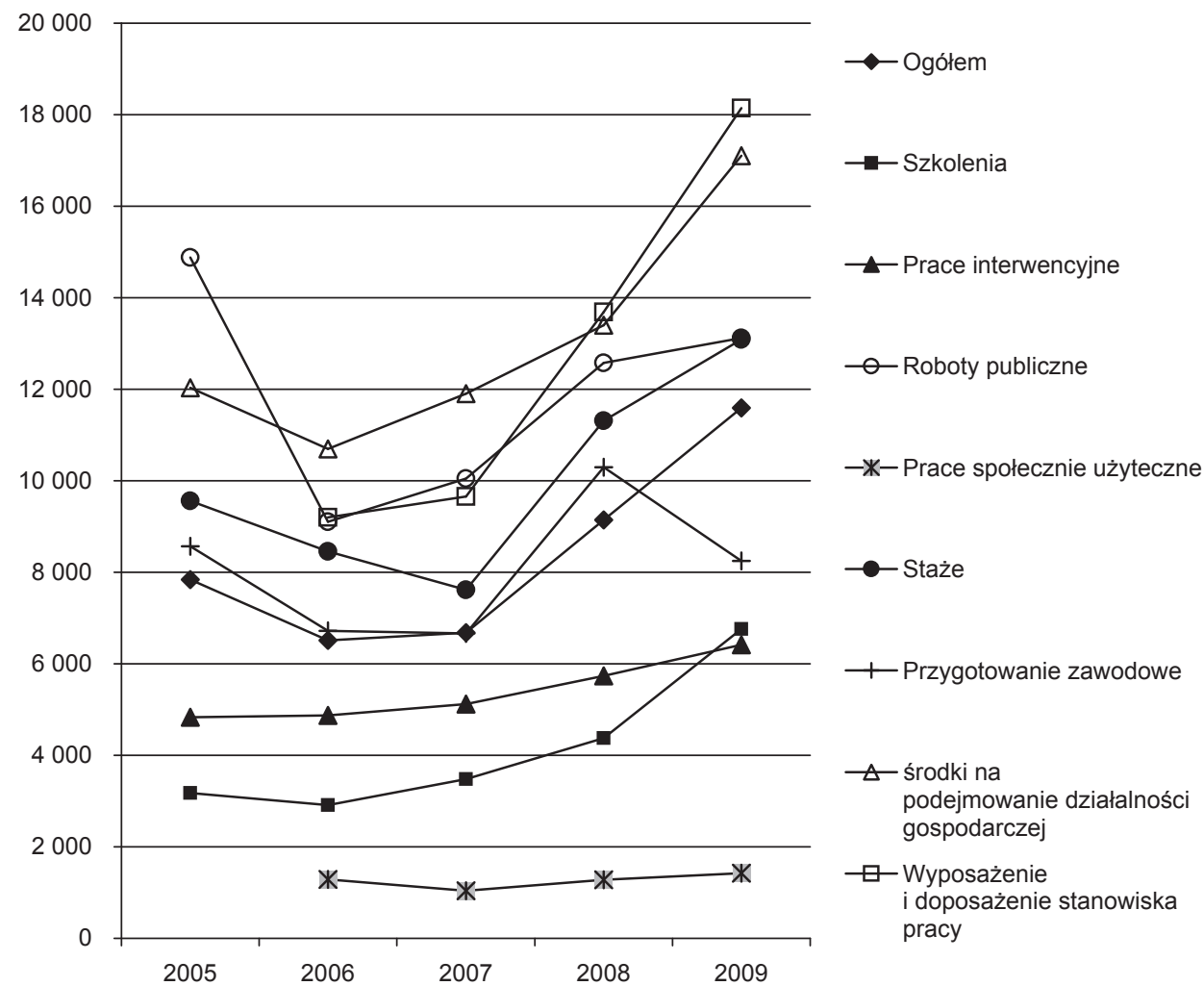

Wykres 4. Koszt ponownego zatrudnienia po skończeniu udziału w aktywnych programach rynku pracy w Polsce w latach 2005-2009 w zł

Źródło: Polska 2006. Raport o rynku pracy oraz zabezpieczeniu społecznym 2006, MPiPS, Warszawa 2006; Efektywność podstawowych form promocji zatrudnienia i aktywizacji zawodowej bezrobotnych finansowanych z Funduszu Pracy w 2007 r., MPiPS Departament Funduszy, Warszawa wrzesień 2008; Efektywność podstawowych form promocji zatrudnienia i aktywizacji zawodowej bezrobotnych finansowanych z Funduszu Pracy w 2008 r., MPiPS Departament Funduszy, Warszawa sierpień 2009; Efektywność podstawowych form aktywizacji zawodowej realizowanych w ramach programów na rzecz promocji zatrudnienia, lagodzenia skutków bezrobocia i aktywizacji zawodowej w 2009 r., Warszawa, lipiec 2010. 
Szkolenia charakteryzowały się stosunkowo niską efektywnością zatrudnieniową, ale ich rola wydaje się nie do przecenienia szczególnie w warunkach rozwoju gospodarek opartych na wiedzy i wysokich kwalifikacjach, którym towarzyszy zazwyczaj występowanie zjawiska bezrobocia strukturalnego. Obserwacja doświadczeń europejskich pozwala stwierdzić, że szkolenia stają się najważniejszym instrumentem w polityce rynku pracy ze względu na zwiększające się ryzyko szybkiej dezaktualizacji kwalifikacji. Proces rozwoju gospodarek opartych na wiedzy będzie ten problem nasilać, podczas gdy pracodawcy będą poszukiwać kandydatów do pracy dobrze przygotowanych do wykonywania zawodu. Jak słusznie zauważa P. Błędowski (2008), w niedługiej przyszłości szkolenia będą uzupełniać i wspierać działanie instrumentów subsydiowania zatrudnienia w szerokim tego słowa znaczeniu.

W Polsce jednak, jak wykazują przytoczone wyżej statystyki, skala szkolenia zawodowego jest nadal niewystarczająca. Zgodnie z zaleceniami Komisji Europejskiej z 1977 r. udział środków na szkolenia i pozostałe formy podnoszenia kwalifikacji w wydatkach na aktywne programy rynku pracy powinien kształtować się na poziomie 25\% (European Commission, 1997). Tymczasem w Polsce kształtuje się na poziomie około 10\%. Oznacza to, że w Polsce nadal bardziej uprzywilejowane są instrumenty zorientowane popytowo, związane z subsydiowaniem zatrudnienia. Biorąc pod uwagę zalecenia Komisji Europejskiej (European Commission, 1997) dotyczące rozszerzenia skali szkolenia bezrobotnych, udział przeszkolonych przez urzędy pracy w ogóle zarejestrowanych bezrobotnych pomimo znaczącego wzrostu w latach 2005 - 2008 kształtuje się na zbyt niskim poziomie. W roku 2009 w związku ze wzrostem liczby osób bezrobotnych udział ten zmniejszył się ponownie i wynosi aktualnie mniej niż 9\%.

\section{ZAKOŃCZENIE}

W analizowanym okresie znacznie wzrosły wydatki na politykę rynku pracy w Polsce, przy jednoczesnym wzroście w wydatkach ogółem wydatków na finansowanie programów aktywnych. Nastąpiło również wzmocnienie kadrowe publicznych służb zatrudnienia. Umożliwiło to objęcie aktywnymi programami polityki rynku pracy znacznie większej niż w poprzednich latach liczby bezrobotnych, co przy spadku poziomu bezrobocia doprowadziło do znacznego zintensyfikowania podejmowanych działań.

Przeprowadzona analiza wykazała, że stosowany miernik efektywności zatrudnieniowej nie jest dobrą miarą w przypadku pomocy w poszukiwaniu pracy, bowiem jest ona ogniwem w całym łańcuchu działań prowadzących do aktywizacji bezrobotnego i daje najlepsze rezultaty po odpowiednim skojarzeniu z innymi 
programami aktywnymi. Ze względu na brak odpowiednich danych nie można również wyznaczyć mierników jej efektywności kosztowej.

Efektywność zatrudnieniowa pozostałych aktywnych programów rynku pracy uzależniona jest w dużej mierze od sytuacji na rynku pracy, co może sugerować występowanie w znacznej skali efektu jałowego biegu. Najwyższą efektywnością zatrudnieniową charakteryzowały się dotacje na podejmowanie działalności gospodarczej oraz wyposażenie i doposażenie stanowisk pracy, ale mogło być to spowodowane niedostosowaną do konstrukcji tego instrumentu metodą pomiaru efektywności zatrudnieniowej. Najniższą efektywność zatrudnieniową wykazywały natomiast szkolenia.

Trzeba jednak podkreślić, że - w przeciwieństwie do szkoleń - wysokie efekty zatrudnieniowe innych instrumentów, szczególnie prac interwencyjnych, jak i środków na utworzenie stanowisk pracy wynikają z zapisów ustawowych. Jak pokazują niektóre badania, pozytywne efekty szkoleń ujawniają się w perspektywie kilku lat. Większość badań ewaluacyjnych koncentruje się bowiem na efektach krótkookresowych (sytuacja uczestnika szkoleń analizowana jest najczęściej w okresie od 3 do 6 miesięcy od zakończenia kursu), a ich wyniki w dużym stopniu odzwierciedlają oddziaływanie efektu zamknięcia związanego z uczestnictwem bezrobotnego w szkoleniu (Fitzenberger, Speckesser, 2005). Dostępne i względnie aktualne wyniki analiz efektywności netto aktywnej polityki rynku pracy w Polsce wskazują, że szkolenia wywierają istotny i pozytywny wpływ na szanse podjęcia zatrudnienia (Bieliński, Bober, Sarzalska, Zawistowski, 2008). Są więc skuteczną i jednocześnie najtańszą formą aktywizacji bezrobotnych.

Szybki wzrost przeciętnego kosztu uczestnictwa w programach aktywnych oraz ponownego zatrudnienia wynikał między innymi z rosnącego udziału dotacji na podejmowanie działalności gospodarczej i tworzenie miejsc pracy, a więc programów najdroższych. Szkolenia należały natomiast do programów stosunkowo tanich. Trzeba również dodać, że dysproporcje między kosztami ponownego zatrudnienia poszczególnych programów były znacznie niższe od dysproporcji kosztów uczestnictwa w nich, co wynikało z ich różnej efektywności zatrudnieniowej.

O efektywności wykorzystywanych usług i instrumentów rynku pracy decyduje szereg czynników. Jednak nawet najlepiej skonstruowany instrument, stosowany przez zdeterminowane służby zatrudnienia o najwyższym przygotowaniu fachowym, dysponujące wystarczającymi środkami materialnymi i szerokimi możliwościami działania nie odniesie skutku jeżeli bezrobotni nie będą zmotywowani do podejmowania pracy. Obserwacje polskiego rynku pracy wskazują, że jest z tym różnie, a część osób uzyskuje status bezrobotnego i stara się za wszelką cenę go utrzymać aby zdobyć bezpłatny dostęp do publicznej opieki zdrowotnej i ubezpieczenia zdrowotnego, mając inne źródła utrzymania. Dla 
urealnienia oceny efektywności funkcjonowania publicznych służb zatrudnienia i stosowanych usług i instrumentów rynku pracy należałoby więc rozdzielić fakt rejestracji w urzędzie pracy od uzyskania prawa do ubezpieczenia zdrowotnego.

\section{LITERATURA}

Bieliński J., Bober M., Sarzalska M., Zawistowski J. (2008), Aktywne polityki na elastycznym rynku pracy [w:] M. Bukowski (red.), Zatrudnienie w Polsce 2007. Bezpieczeństwo na elastycznym rynku pracy, MPiPS, Warszawa.

Błędowski P. (2008), Efektywność ustug i instrumentów rynku pracy stużących podnoszeniu kwalifikacji bezrobotnych - rekomendacje na podstawie doświadczeń wybranych krajów Unii Europejskiej [w:] P. Błędowski, B. Błaszczyk, M. Fedorczuk, Cz. Kliszko, P. Kubicki, Kierunki modyfikacji rozwiazań prawno-organizacyjnych w celu zwiększania efektywności ustug $i$ instrumentów rynku pracy stużących podnoszeniu kwalifikacji, raport z badań, MPiPS, Warszawa.

European Commission (1997), European Commission Proposal for Guidelines for Member States Employment Policies, Brussels.

Fitzenberger B., Speckesser S. (2005), Employment Effects of the Provision of Specific Skills and Techniques in Germany, ZEW, Discussion Paper No. 77.

Kryńska E. (red.) (2009), Flexicurity w Polsce, diagnoza i rekomendacje. Raport końcowy z badań, MPiPS, Departament Rynku Pracy, Warszawa.

Kryńska E., Kwiatkowski E., Zarychta H. (1998), Polityka państwa na rynku pracy $w$ Polsce w latach dziewięćdziesiąych, IPiSS, Warszawa.

Kukulak-Dolata I. (2007), Powiatowe urzędy pracy jako instytucje rynku pracy. Analiza wyników badań, w: I. Kukulak-Dolata, J. Pichla, Rola publicznych stużb zatrudnienia $i$ agencji zatrudnienia na rynku pracy, IPiSS, Warszawa.

Szewczyk A. (2004), Informacja w walce z bezrobociem, Wydawnictwo Naukowe PWN, Warszawa.

Sztanderska U. (2008), Publiczne stużby zatrudnienia a wyzwania rynku pracy, [w:] Analiza funkcjonowania urzędów pracy po ich właczeniu do administracji samorzadowej, MPiPS, Departament Rynku Pracy, Warszawa.

Wiśniewski Z, Zawadzki K. (red.) (2010), Aktywna polityka rynku pracy w Polsce w kontekście europejskim, UMK, Torun.

Wójcicka I., Sztandar-Sztanderska K., Zielińska M. (2008), Klienci powiatowych urzędów pracy, w: Analiza funkcjonowania urzędów pracy po ich właczeniu do administracji samorzadowej, MPiPS, Departament Rynku Pracy, Warszawa.

Zawadzki P. W. (2006), System pośrednictwa pracy w warunkach członkostwa Polski w Unii Europejskiej, Warszawa, praca doktorska, maszynopis. 


\section{LABOUR MARKET ACTIVE PROGRAMMES IN POLAND IN 2005-2009}

Abstract. The aim of this paper is to show quantity and structure spending from Labour Fund for labour market programmes, number and structure unemployed under these programmes and their effectiveness in Poland in 2005-2009.

In this period there was a significant increase in spending from Labour Fund for active programmes and number unemployed under them. Generally, it was increased the employment effectiveness of these programmes, but the cost of them was increased too.

K e y w or d s : labour market, labour market policy, labour market active programmes. 